\title{
Pemanfaatan teknologi Informasi, Sosialisasi Pajak, Pengetahuan Perpajakan, dan Kepatuhan Pajak
}

\author{
Ajat Sudrajat ${ }^{1}$, Arles Parulian Ompusunggu ${ }^{2}$ \\ 1,2 Universitas Pancasila, Jl. Srengseng Sawah, Jagakarsa, Jakarta Selatan 12640
}

\section{NFO ARTIKEL $\quad A B S T R A C T$}

\section{JEL Classification:}

$\mathrm{H} 20$

K34

\section{Keywords:}

utilization information

technology,

socialization of taxes, tax knowledge,

tax compliance.
The taxpayer compliance in Indonesia to convey annual tax return is still low that only by $53.70 \%$ in 2012. This is one of the causes that tax revenues in Indonesia is still low. This study was conducted to test the effect of Utilization of Information Technology, socialization of taxes and Tax Knowledge on Tax compliance of individual taxpayer in The South Jakata Regional Office Directorate General of Taxation (DGT). This reaserch analyzed the questionnaires of primary data from 400 respondends of taxpayer. The testing of these variable using multiple regression analysis with SPSS version 21, with significance level of alpha $5 \%$. The results showed that the Utilization of Information Technology, socialization of taxes and tax knowledge has positive influence and significant effect on tax compliance partially. While simultaneously affect on tax compliance. These findings contribute to the General of Taxation (DGT) can add as an alternative method to improve the taxpayer compliance. It can be concluded that tax compliance is affected by the utilization of information technology, socialization of taxes and tax knowledge and other variables not examined in this study.

\section{A B S T R A K}

Kepatuhan pajak Wajib Pajak di Indonesia dalam menyampaikan SPT tahunan masih rendah yaitu hanya sebesar $53,70 \%$ pada tahun 2012. Hal ini merupakan salah satu penyebab masih rendahnya penerimaan pajak di Indonesia. Penelitian ini dilakukan untuk menguji secara empiris pengaruh Pemanfaatan Teknologi Informasi, Sosialisasi Pajak dan Pengetahuan Pajak Terhadap Kepatuhan Wajib Pajak Orang Pribadi yang ada di Kanwil DJP Jakarta Selatan. Penelitian ini menganalisis kuesioner dari data primer yang berasal dari jawaban responden sebanyak 400 Wajib Pajak. Pengujian variabel penelitian menggunakan analisis regresi berganda dengan program SPSS versi 21 dengan tingkat kesalahan 5\%. Hasil penelitian menunjukan bahwa pemanfaatan tekhnologi informasi, sosialisasi pajak dan pengetahuan pajak berpengaruh positif dan signifikan terhadap kepatuhan Wajib Pajak secara parsial. Sedangkan pengujian secara bersama- sama (simultan) berpengaruh terhadap kepatuhan pajak. Temuan ini dapat menambah kontribusi kepada DJP sebagai metode alternatif untuk meningkatkan kepatuhan Wajib Pajak. Dapat disimpulkan bahwa kepatuhan Wajib Pajak dipengaruhi oleh Pemanfaatan tekhnologi Informasi, Sosialisasi Pajak dan Pengetahuan Pajak dan variabel lain yang tidak diuji dalam penelitian ini. 


\section{Pendahuluan}

Kepatuhan pajak Wajib Pajak di Indonesia dalam menyampaikan SPT tahunan masih rendah yaitu hanya sebesar 53,70\% pada tahun 2012 (Antaranews, 21 November 2013). Rendahnya kepatuhan pajak merupakan salah satu penyebab masih rendahnya penerimaan pajak di Indonesia, hal ini ditunjukan dengan masih relatif kecilnya tax ratio (yaitu jumlah pajak yang berhasil dipungut dibandingkan dengan Produk Domestik Bruto). Sejak diubahnya sistem perpajakan dari Official Assessment ke Self Assessment pada tahun 1983, dituntut peran aktif dari masyarakat dalam pemenuhan kewajiban perpajakannya secara mandiri. Sebagai gambaran, dari data Direktorat Jenderal Pajak (Kompas, 6 Maret 2014) bahwa potensi penerimaan pajak dari pajak orang pribadi belum tergali maksimal sedikitnya Rp 150 triliun.

Masalah kepatuhan pajak adalah pada pengenaan pajak itu sendiri Menggambarkan dan menjelaskan pola - pola yang diamati mengenai ketidakpatuhan pajak yang akhirnya dapat menemukan cara untuk mengurangi ketidakpatuhan pajak tersebut sangat penting bagi Negara di seluruh dunia. Ditambahkan bahwa ekonomi kepatuhan pajak dapat didekati dari berbagai perspektif yaitu: kepatuhan pajak dapat dipandang sebagai masalah keuangan publik, penyelenggaraan hukum, struktur organisasi, tersedianya jumlah tenaga kerja atau budaya atau kombinasi dari semuanya (Andreoni et all, 2006).

Kepatuhan pajak adalah suatu keadaan dimana wajib pajak memenuhi semua kewajiban perpajakan dan melaksanakan hak perpajakannya (Nurmantu,2006).. Berdasarkan data Kementrian Keuangan Republik Indonesia (2012) bahwa kepatuhan wajib pajak Negara Indonesia tahun 2012 adalah sebesar 53,70\%. Berdasarkan Buku Kemenkeu Dasar-Dasar Praktek Penyusunan APBD di Indonesia, bahwa jumlah wajib pajak yang terdaftar selama tahun 2007-2012 mengalami kenaikan setiap tahuan. Tahun 2012 Jumlah Wajib Pajak terdaftar mengalami kenaikan sebesar 7.118.252 Wajib Pajak, sedangkan kenaikan penyampaian SPT Tahunan PPh hanya sebesar 3.991.723 Wajib Pajak. Hal ini menunjukan bahwa kepatuhan wajib pajak masih relatif rendah jika dibandingkan dengan jumlah wajib pajak yang mendaftar.

Kepatuhan Wajib Pajak adalah salah satu faktor penting dalam sistem perpajakan modern. Namun tidaklah mudah untuk diwujudkan, karena masyarakat belum patuh memenuhi kewajiban dalam hal mendaftar menjadi Wajib Pajak, membayar dan melaporkan kewajiban perpajakannya. Beberapa alasan yang menjadi ketidakpatuhan (Yessi et al, 2012) yaitu:

1. keadilan sistem perpajakan,

2. norma sosial dan moral,

3. sanksi legal

4. religiulitas, dan

5. niat berprilaku tidak patuh.

Seperti yang dikemukakan oleh Nasucha (2004) bahwa dalam sistem perpajakan self assessment, prosedur organisasi baik yang mencakup prosedur dalam organisasi maupun prosedur yang berkaitan dengan pelayanan kepada Wajib Pajak perlu mendapatkan perhatian paling besar dalam pelaksanaan reformasi administrasi perpajakan agar timbul kepatuhan Wajib Pajak. Berbagai cara telah dilakukan oleh pemerintah agar dapat meningkatkan kepatuhan Wajib Pajak yang masih rendah, seperti meningkatkan pemanfaatan teknologi informasi, sosialisasi pajak, meningkatkan pengetahuan pajak kepada masyarakat. Penelitian ini bertujuan menguji secara empiris pemanfaatan teknologi infromasi, spsialisai pajak dan pengetahuan perpajakan terhadap kepatuhan pajak.

Putri et al (2012) menyimpulkan bahwa sosialisasi perpajakan berpengaruh terhadap kepatuhan Wajib Pajak, hal ini berarti bahwa pemberianpemahamankepadaWajibPajakmelalui sosialisasi perpajakan merupakan hal penting mengingat semakin maraknya aksi penghindaran pajak atau tax evasion yang berakibat akan mengurangi masuknya dana pajak ke kas negara, atau bahkan tidak ada dana yang masuk ke kas negara. Hasil penelitian ini bertentangan dengan hasil penelitian yang dilakukan oleh Lidya (2013) 
yang berjudul pengaruh sosialisasi perpajakan, pelayanan fiskus, dan sanksi perpajakan terhadap kepatuhan Wajib Pajak orang pribadi pada Kantor Pelayanan Pajak Pratama Manado dan Kantor Pelayanan Pajak Pratama Bitung. Penelitian yang dilakukan oleh Lidya menyimpulkan bahwa sosialisasi perpajakan, pelayanan fiskus dan sanksi perpajakan tidak berpengaruh terhadap kepatuhan Wajib Pajak Orang Pribadi di KPP Pratama Manado dan KPP Pratama Bitung. Hal ini menunjukkan adanya upaya dari KPP Pratama Manado dan KPP Pratama Bitung untuk meningkatkan kesadaran masyarakat di kedua kota tersebut terhadap pentingnya pajak bagi pembangunan, sehingga dapat meningkatkan Kepatuhan Wajib Pajak Orang Pribadi.

$$
\text { Hasil penelitian Witono }
$$
menyatakan bahwa semakin baik pengetahuan Wajib Pajak dan konsultan pajak terhadap peraturan pajak maka semakin tinggi tingkat kepatuhan Wajib Pajak dengan Keadilan Pajak sebagai variabel intervening. Penelitian yang serupa juga dilakukan oleh Nazir (2010) dengan judul pengaruh pengetahuan pajak dan sistem administrasi perpajakan terhadap kepatuhan Wajib Pajak. Hasil pengujian hipotesis dalam penelitiannya menyatakan bahwa terdapat pengaruh positif dan signifikan antara variabel tingkat pengetahuan pajak terhadap tingkat kepatuhan Wajib Pajak.

Penelitian yang serupa adalah penelitian yang dilakukan oleh Anggraini (2012) dengan judul pengaruh pengetahuan pajak, persepsi tentang petugas pajak dan sistem administrasi pajak terhadap tingkat kepatuhan Wajib Pajak orang pribadi yang dilakukan di Kantor Pelayanan Pajak (KPP) Surabaya. Anggraeni menyimpulkan bahwa variabel pengetahuan pajak memiliki pengaruh positif terhadap tingkat kepatuhan Wajib Pajak Orang Pribadi. Selain itu peneliti juga ingin membuktikan model penelitian yang diungkapkan oleh Cristensen et al. (1994) bahwa Wajib Pajak yang memiliki pengetahuan yang baik, akan memiliki persepsi keadilan yang positif terhadap sistem pajak yang berakibat tingkat kepatuhan pajak lebih tinggi. Penelitian ini mengkaji tingkat kepatuhan WP OP
Kanwil DJP Jakarta Selatan. karena berdasarkan data dari Kantor Pelayanan Pajak Hubungan Masyarakat (KP2 Humas) diketahui bahwa tingkat kepatuhan Wajib Pajak menurun dari tahun ke tahun. Penelitian ini dilakukan dengan menggunakan beberapa variabel bebas yang juga pernah digunakan dalam penelitian sebelumnya Seperti Pemanfaatan Teknologi Informasi, Sosialisasi Pajak dan Pengetahuan Pajak terhadap Kepatuhan perpajakan.

Alasan memilih variabel pemanfaatan tekhnologi informasi, sosialisasi pajak dan pengetahuan pajak karena pada zaman sekarang, Wajib Pajak telahmelek teknologi dalam melaksanakan pekerjaan-pekerjaan harian ataupun keperluan bisnis seperti penggunaan internet, laptop maupun komputer. Dengan demikian, diharapkan agar kewajiban perpajakan dapat dilakukan dengan mudah menggunakan tekhnologi informasi. Sosialisasi pajak diperlukan agar Wajib Pajak mengetahui secara universal peran penting pajak untuk pembangunan Negara sehingga mampu ikut serta dalam membangun Negara dengan membayar pajak. Selain itu, pengetahuan pajak diperlukan agar Wajib Pajak mengetahui tatacara perpajakan sehingga pelaksanaan dalam hal melakukan kewajiban perpajakannya sesuai dengan undang-undang yang berlaku.

\section{Telaah Teori dan Pengembangan Hipotesis}

Atribusi merupakan salah satu proses pembentukan kesan. Atribusi mengacu pada bagaimana orang menjelaskan penyebab perilaku orang lain atau dirinya sendiri. Atribusi adalah proses di mana orang menarik kesimpulan mengenai faktor-faktor yang mempengaruhi perilaku orang lain (Fikriningrum, 2012). Teori atribusi yang diperkenalkan oleh Weiner (1980) menyatakan bahwa teori atribusi adalah teori kontemporer yang paling berpengaruh dengan implikasi untuk motivasi akademik. Pada dasarnya, teori atribusi menyatakan bahwa bila individu-individu mengamati perilaku seseorang, mereka mencoba untuk menentukan apakah 
itu ditimbulkan secara internal atau eksternal (Robbins, 2007). Perilaku yang disebabkan secara internal adalah perilaku yang diyakini berada di bawah kendali pribadi individu itu sendiri, sedangkan perilaku yang disebabkan secara eksternal adalah perilaku yang dipengaruhi dari luar, artinya individu akan terpaksa berperilaku karena situasi.

Teori Stewardship mengasumsikan bahwa adanya hubungan yang kuat antara kepuasan dan kesuksesan organisasi (Donaldson \& Davis, 1989, 1991). Kesuksesan organisasi menggambarkan maksimalisasi utilitas kelompok principals dan manajemen. Maksimalisasi utilitas kelompok ini pada akhirnya akan memaksimumkan kepentingan individu yang ada dalam kelompok organisasi tersebut. Teori stewardship dapat diterapkan pada penelitian akuntansi organisasi sektor publik seperti organisasi pemerintahan (Morgan, 1996; David, 2006 dan Thorton, 2009) dan non profit lainnya (Vargas, 2004; Caers Ralf, 2006 dan Wilson 2010) yang sejak awal perkembangannya, akuntansi organisasi sektor publik telah dipersiapkan untuk memenuhi kebutuhan informasi bagi hubungan antara stewards dengan principals. Akuntansi sebagai penggerak (driver) berjalannya transaksi bergerak kearah yang semakin kompleks dan diikuti dengan tumbuhnya spesialisasi dalam akuntansi dan perkembangan organisasi sektor publik. Kondisi semakin kompleks dengan bertambahnya tuntutan akan akuntabilitas pada organisasi sektor publik, principal semakin sulit untuk melaksanakan sendiri fungsi-fungsi pengelolaan. Pemisahan antara fungsi kepemilikan dengan fungsi pengelolaan menjadi semakin nyata. Berbagai keterbatasan, pemilik sumber daya (capital suppliers/principals) mempercayakan (trust $=$ amanah) pengelolaan sumber daya tersebut kepada pihak lain (steward = manajemen) yang lebih capable dan siap. Kontrak hubungan antara stewards dan principals atas dasar kepercayaan (amanah = trust), bertindak kolektif sesuai dengan tujuan organisasi, sehingga model yang sesuai pada kasus organisasi sektor publik adalah stewardship theory Kepatuhan pajak identik dengan kesediaan seorang wajib pajak dalam memenuhi peraturan perpajakannya. Pengertian kepatuhan Wajib Pajak menurut Safri Nurmantu menyatakan bahwa: Suatu keadaan dimana wajib pajak memenuhi semua kewajiban perpajakan dan melaksanakan hak perpajakannya.

Nurmantu (2005) mengidentifikasi kepatuhan menjadi dua yaitu 1. Kepatuhan formal adalah suatu keadaan dimana Wajib Pajak memenuhi kewajiban secara formal sesuai dengan ketentuan dalam undang-undang perpajakan. 2. Kepatuhan material adalah suatu keadaan dimana wajib pajak secara substantif/ hakikatnya memenuhi semua ketentuan material perpajakan yaitu sesuai isi dan jiwa Undangundang pajak. Kepatuhan material juga dapat meliputi kepatuhan formal.

Pemanfaatan teknologi informasi khususnyadalamadministrasipajakmenyebabkan terjadinya berbagai macam perubahan seperti tugas yang dilakukan manusia digantikan oleh tenaga mesin atau elektronik. Menurut Wardiana (2002) teknologi informasi adalah: "Suatu teknologi yang digunakan untuk mengolah data, termasuk memproses, mendapatkan, menyusun, menyimpan, memanipulasi data dalam berbagai cara untuk menghasilkan informasi yang berkualitas, yaitu informasi yang relevan, akurat dan tepat waktu, yang digunakan untuk keperluan pribadi, bisnis, dan pemerintahan dan merupakan informasi yang strategis untuk pengambilan keputusan". Penggunaan tekhnologi informasi dalam moderenisasi perpajakan yang berbasis e-system diharapkan dapat meningkatkan kepatuhan pajak juga dapat meningkatkan kepercayaan masyarakat terhadap administrasi perpajakan. Pujianti (2012) menyatakan bahwa tujuan penggunaan tekhnologi informasi dalam perpajakan adalah menghemat waktu, mudah, akurat dan paperless. Adapun e-System perpajakan dibagi menjadi $e$ - registration, e-filling dan e-Billing.

Salah satu faktor yang bisa ditekankan oleh aparat dalam meningkatkan kesadaran dan kepatuhan pajak adalah dengan cara mensosialisasikan peraturan pajak baik itu melalui penyuluhan, seruan moral baik dengan media billboard, baliho, maupun membuka 
situs peraturan pajak yang setiap saat bisa diakses oleh Wajib Pajak (Witono, 2008). Sosialisasi yang diberikan kepada masyarakat dimaksudkan untuk memberikan pengertian kepada masyarakat akan pentingnya membayar pajak. Menurut Nasution (2009), Sosialisasi merupakan: "Proses bimbingan individu ke dalam dunia sosial. Sosialisasi dilakukan dengan mendidik individu tentang kebudayaan yang harus dimiliki dan diikutinya, agar ia menjadi anggota yang baik dalam masyarakata dan alam berbagai kelompok khusus, sosialisasi dapat dianggap sama dengan pendidikan". Menurut Meliono (2007) Pengetahuan adalah informasi atau maklumat yang diketahui atau disadari oleh seseorang. Pengetahuan termasuk, tetapi tidak dibatasi pada deskripsi, hipotesis, konsep, teori, prinsip dan prosedur yang secara Probabilitas Bayesian adalah benar atau berguna. Pengetahuan seseorang dipengaruhi oleh beberapa faktor, diantaranya pendidikan, media dan keterpaparan informasi (Meliono dkk, 2007).

Kepatuhan Wajib Pajak merupakan aspek yang penting dalam meningkatkan penerimaan negara dari sektor pajak. Apabila Wajib Pajak yang patuh dalam membayar dan melaporkan SPT terus meningkat maka akan semakin meningkatkan rasio kepatuhan pajak sehingga berpengaruh kepada pendapatan negara dari sektor pajak. Selain itu terdapat faktor-faktor lain yang dapat mempengaruhi tingkat kepatuhan Wajib Pajak dalam penelitian ini yaitu pemanfaatan teknologi, sosialisasi pajak dan pengetahuan pajak. Ditjen Pajak sebagai organisasi pemerintah yang diberi wewenang untuk mengelola perpajakan menyadari sepenuhnya bahwa tanpa adanya improvisasi di bidang teknologi informasi, dinamika yang berkembang di masyarakat terutama dinamika bisnis tidak akan dapat diantisipasi (Prawirodidirdjo , 2007)

\section{H1:Pemanfaatan teknologi informasi berpengaruh positif terhadap kepatuhan Wajib Pajak orang pribadi.}

Salah satu faktor yang bisa ditekankan oleh aparat dalam meningkatkan kesadaran dan kepatuhan pajak adalah dengan cara mensosialisasikan peraturan pajak baik itu melalui penyuluhan, seruan moral baik dengan media billboard, baliho, maupun membuka situs peraturan pajak yang setiap saat bisa diakses oleh Wajib Pajak (Witono, 2008:197)

\section{H2: Sosialisasi pajak berpengaruh positif terhadap kepatuhan Wajib Pajak orang pribadi.}

PengetahuanWajib Pajak tentang pajak yang baik akan dapat memperkecil adanya tax evation, Palil (2005). Hal senada juga ditemukan oleh Kassipillai, ia menyatakan pengetahuan tentang pajak merupakan hal yang sangat penting bagi berjalannya SAS (Self Assesment System) . Pengetahuan tentang peraturan pajak akan mempengaruhi sikap Wajib Pajak terhadap kawajiban pajak. Hal serupa juga dinyatakan oleh Vogel, 1974, Spicer dan Lounstedh, 1976, Song dan Yarbourgh, 1978, Laurin, 1976, Kinsey dan Grasmick, 1993. Mereka menemukan bahwa pengetahuan pajak akan bertambah dengan panjangnya masa pendidikan yang dilakukan dan kursus, walaupun secara tidak langsung tidak ditemukan adanya kaitan dengan sikap Wajib Pajak Dalam Palil, (2005).

\section{H3 : Pengetahuan pajak berpengaruh positif terhadap kepatuhan Wajib Pajak orang priadi}

Sebelum dilakukannya penelitian ini, telah ditulis beberapa penelitian mengenai pengaruh pemanfaatan teknologi informasi, sosialisasi pajak, dan pengetahuan pajak terhadap kepatuhan Wajib Pajak orang pribadi. Penelitian-penelitian tersebut akan dikemukakan antara lain: Penelitian yang dilakukan oleh Palil (2013) yang berjudul The Perception of Tax Payers on Tax Knowledge and Tax education with Level of Tax Compliance: A Study the influences of Religiosity dimana hasil penelitiannya yaitu kepatuhan pajak responden lebih rendah dibandingkan dengan pendidikan dan pengetahuan mereka terhadap pajak dan nilai-nilai agama memainkan peran yang sangat penting untuk membuat Wajib Pajak bertanggung jawab atas kepatuhan pajak. Penelitian yang dilakukan oleh Oktaviane Lydia Winerungan (2013) yang berjudul Sosialisasi Perpajakan, 
Pelayanan Fiskus dan Sanksi Perpajakan terhadap Kepatuhan WPOP di KPP Manado dan di KPP Bitung dimana hasil penelitiannya yaitu Pengaruh sosialisasi perpajakan, pelayanan fiskus dan sanksi perpajakan terhadap kepatuhan Wajib Pajak Orang Pribadi di KPP Bitung lebih besar dari pada pengaruh sosialisasi perpajakan, pelayanan fiskus dan sanksi perpajakan terhadap kepatuhan Wajib Pajak orang pribadi di KPP Manado. Penelitian yang sama pernah dilakukan oleh Kesdu(2012) yang berjudul Analisis Kepuasan Wajib Pajak: Pendekatan terhadap Penggunaan Teknologi Informasi dan Self Assessment dimana hasil penelitiannya yaitu Pemanfaatan Teknologi Informasi dengan Sistem self assesment berpengaruh secara signifikan terhadap kepuasan Wajib Pajak.

\section{Metode}

Penelitian ini menggunakan pendekatan kuantitatif, dengan fokus pada pengukuran dan deskripsi hubungan antara pemanfaatan teknologi informasi, sosialisasi pajak, dan pengetahuan pajak terhadap kepatuhan wajib pajak. Namun tidak berarti sama sekali mengabaikan pendekatan kualitatif, khususnya untuk menjelaskan hasil pengukuran yang menggunakan instrumen analisis statistik. Penelitian ini mengkaji empat variabel, yaitu tiga independent variable dan satu dependent variable. Independent variable terdiri atas pemanfaatan teknologi informasi (X1), sosialisasi pajak (X2), dan pengetahuan wajib pajak (X3). Sedangkan dependent variable adalah kepatuhan wajib pajak (Y).

Jenis metode penelitian yang digunakan adalah metode survei, yaitu penelitian yang memfokuskan pada data sampel yang diambil dari populasi yang sudah ditetapkan dalam penelitian dan penelitian ini tidak hanya menggambarkan dengan jelas fakta empiris yang diterima di lapangan tetapi mengalami pengaruh variabel yang satu dengan variabel yang lain. Jenis data yang digunakan dalam penelitian ini adalah data primer. Data ini dapat dikumpulkan dengan beberapa cara, antara lain: kuisioner, observasi, dan hasil pengujian (Sekaran, 2006). Sumber data primer dalam penelitian ini diperoleh langsung dari WP OP yang terdaftar pada KPP Pratama di Kanwil DJP Jakarta Selatan yang berupa kuesioner yang telah diisi oleh para WP OP yang menjadi responden terpilih.

Disamping itu, data penelitian ini termasuk data kualitatif. Data kualitatif ini diperoleh melalui penyebaran kuisioner yang kemudian diubah menjadi data kuantitatif, diangkakan berupa scoring untuk masingmasing pernyataan dan skala yang digunakan dalam penelitian ini untuk pembobotan item kuisioner adalah menggunakan skala Likert dengan menggunakan item pernyataan positif untuk keseluruhan pernyataan. Adapun tingkatan scoring dapat dilihat pada Tabel 1.

Populasi dalam penelitian ini adalah para Wajib Pajak orang pribadi (WP OP) yang ada di Kanwil DJP Jakarta Selatan. Berdasarkan data dari Kanwil DJP Jakarta Selatan, hingga akhir tahun 2012 tercatat sebanyak 647.739 yang merupakan WPOP efektif. Tidak semua WP OP efektif ini menjadi objek dalam penelitian ini karena jumlahnya sangat besar dan guna efisiensi waktu dan biaya. Dalam penelitian ini untuk memperoleh jumlah sampel dipergunakan Rumus yang digunakan adalah sebagai berikut: (Slovin dalam Umar, 2004).

\begin{tabular}{|c|c|c|c|}
\hline Kriteria & Nilai/Skor & Kriteria & Nilai/Skor \\
\hline Sangat Setuju & 5 & Sangat Setuju & 1 \\
\hline Setuju & 4 & Setuju & 2 \\
\hline Tidak Tahu & 3 & Tidak tahu & 3 \\
\hline Tidak Setuju & 2 & Tidak Setuju & 4 \\
\hline Sangat Tidak Setuju & 1 & Sangat Tidak Setuju & 5 \\
\hline
\end{tabular}


$\mathrm{n}=\mathrm{N}$

$1+\mathrm{N}(\mathrm{e}) 2$

Keterangan: $\mathrm{n}=$ Sampel

$\mathrm{N}=$ Populasi Wajib Pajak

$\mathrm{e}=$ error (kesalahan) $5 \%$

Berdasarkan data dari Kantor Wilayah DJP Jakarta Selatan per tanggal 13 maret 2014 bahwa hingga akhir tahun 2012 tercatat sebanyak 647.739 WP OP yang merupakan WP OP efektif. Maka Jumlah sampel untuk penelitian dengan margin of error max ditentukan $5 \%$ adalah:

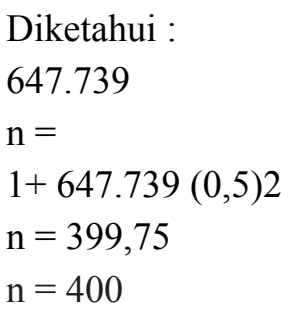

Sehingga jumlah sampel yang diambil dalam penelitian ini adalah sebanyak 400 sampel yang merepresentasikan populasi yang ada. Perhitungan jumlah sampel yang diambil untuk setiap KPP berdasarkan Proportional Sampling.

Dari hasil penyebaran kuesioner sebesar 400 sampel, maka dibuat rentang klasifikasi untuk menentukan skala pembobotan pada skala likert (Supranoto, 2009).Alasan pemakaian pembobotan pada penelitian ini adalah karena setiap variabel mempunyai lebih dari satu indikator pernyataan, sehingga untuk mengetahui tinggi rendahnya tanggapan responden untuk setiap variabel, maka dibuat rentang klasifikasi untuk pembobotan indikator untuk setiap variabel.

Uji validitas digunakan untuk mengukur sah atau valid tidaknya suatu kuesioner. Suatu kuesioner dikatakan valid jika pertanyaan pada kuesioner mampu untuk mengungkapkan sesuatu yang akan diukur oleh kuesioner tersebut sedangkan Uji reliabilitas merupakan alat untuk mengukur suatu kuesioner yang merupakan indikator dari variabel atau konstruk. Suatu kuesioner dikatakan reliable atau handal jika jawaban seseorang terhadap pernyataan adalah konsisten atau stabil dari waktu ke waktu (Ghozali, 2011).

Pengujian asumsi klasik diperlukan untuk mengetahui apakah hasil estimasi regresi yang dilakukan benar-benar bebas dari adanya gejala heteroskedastisitas, gejala multikolinearitas, dan gejala autokorelasi. Model regresi akan dapat dijadikan alat estimasi yang tidak bias jika telah memenuhipersyaratanBLUE(bestlinearunbiased estimator) yakni tidak terdapat heteroskedastistas, tidak terdapat multikolinearitas, dan tidak terdapat autokorelasi.

Uji multikolinearitas adalah untuk menguji apakah pada model regresi ditemukan adanya korelasi antar variabel bebas (independen). Apabila terjadi korelasi, maka dinamakan terdapat problem multikolinearitas (Ghozali, 2011).

Menurut Ghazali (2011) uji autokorelasi bertujuan menguji apakah dalam suatu model regresi linier ada korelasi antara kesalahan pengganggu pada periode $t$ dengan kesalahan pada periode t-1 (sebelumnya). Jika terjadi korelasi, maka dinamakan ada problem autokorelasi. Autokorelasi muncul karena observasi yang berurutan sepanjang waktu berkaitan satu sama lain. Masalah ini timbul karena residual (kesalahan pengganggu) tidak bebas dari satu observasi ke observasi lainnya.

Uji normalitas digunakan untuk menguji apakah dalam model regresi, kedua variabel (bebas maupun terikat) mempunyai distribusi normal atau setidaknya mendekati normal (Ghozali, 2011). Pada prinsipnya normalitas dapat dideteksi dengan menggunakan Uji Kolmogorov-Smirnov. Dasar pengambilan keputusannya adalah (Ghozali, 2011) persamaan regresi linier berganda dari penelitian ini adalah sebagai berikut:

$$
\mathrm{Y}=\alpha+\beta 1 \mathrm{X} 1+\beta 2 \mathrm{X} 2+\beta 3 \mathrm{X3}+\mathrm{e}
$$

dalam hal ini:

$$
\begin{aligned}
& \mathrm{Y}=\text { Kepatuhan Wajib Pajak } \\
& \alpha=\text { Konstanta } \\
& \beta=\text { Koefisien Regresi } \\
& \mathrm{X} 1=\text { Pemanfaatan Teknologi Informasi } \\
& \mathrm{X} 2=\text { Sosialisasi pajak } \\
& \mathrm{X} 3=\text { Pengetahuan Pajak } \\
& \mathrm{e}=\text { error }
\end{aligned}
$$




\section{Hasil Penelitian dan Pembahasan}

Agar dapat mengetahui seberapa besar pengaruh Pemanfaatan Teknologi Informasi, Sosialisasi Pajak, Pengetahuan Pajak Terhadap Kepatuhan Wajib Pajak pada Kantor Pelayanan Pajak Pratama di Kantor Wilayah DJP Jakarta Selatan secara parsial, maka dilakukan pengujian terhadap garis regresi tersebut melalui hipotesis. Hasil pengujian terangkum dalam Tabel 2.

\section{Pengaruh Pemanfaatan Teknologi Informasi terhadap Kepatuhan Wajib Pajak.}

Berdasarkan hasil pengujian, Nilai tersebut lebih besar daripada ttabel yaitu sebesar 1,690. Karena thitung $>$ ttabel, maka Ho ditolak yang artinya dapat disimpulkan bahwa terdapat hubungan yang positif dan signifikan antara variabel Pemanfaatan Teknologi Informasi dan Kepatuhan Wajib Pajak pada Kantor Pelayanan Pajak Pratama di Kantor Wilayah DJP Jakarta Selatan. Temuan ini konsisten dengan hasil penelitian Hervyani (2011) dan Kesdu (2012) yang juga menunjukan bahwa pemanfaatan tekhnologi informasi berpengaruh terhadap kepatuhan pajak. Pemanfaatan tekhnologi informasi dengan e-system dapat mempermudah Wajib Pajak dalam melaporkan pajak sehingga kepatuhan Wajib Pajak meningkat.

SepertiyangdikemukakanNasucha(2004) dalam Rahayu (2009), bahwa dalam menilai keberhasilan penerimaan pajak perlu diperhatikan pencapaian sasaran administrasi perpajakan yang salah satunya adalah meningkatkan kepatuhan pajak. Program kegiatan penerapan sasaran administrasi perpajakan diwujukan melalui pemanfaatan tekhnologi yang berbasis $e$-system seperti e-SPT, e-Filing, e-Payment, Taxpayer"es Account, e-Registration, dan e-Counceling. Melalui reformasi tersebut diharapkan mekanisme kontrol menjadi lebih efektif yang ditunjang oleh adanya penerapan kode etik pegawai Direktorat Jenderal Pajak yang mengatur perilaku pegawai dalam melaksanakan tugasnya (Rahayu,2009).

\section{Pengaruh Sosialisasi Pajak terhadap Kepatuhan Wajib Pajak.}

Nilai thitung lebih besar daripada ttabel yaitu sebesar 1,690. Karena thitung $>$ ttabel, maka maka Ho ditolak yang artinya dapat disimpulkan bahwa terdapat hubungan yang signifikan antara variabel Sosialisasi Pajak dan Kepatuhan Wajib Pajak pada Kantor Pelayanan Pajak Pratama di Kantor Wilayah DJP Jakarta Selatan. Temuan ini konsisten dengan hasil penelitian Putri, dkk (2012) menunjukan bahwa sosialisasi pajak berpengaruh terhadap kepatuhan pajak. Suatu informasi pajak yang disampaikan kepada Wajib Pajak melalui sosialisasi dapat meningkatkan kepatuhan Wajib Pajak.

Sosialisasi Pajak yang mempunyai indikator peraturan perpajakan, media, penyuluhan dan seminar, informasi langsung, talkshow, dan wawasan sudah dapat meningkatkan kepatuhan Wajib Pajak pada Kantor Pelayanan Pajak Pratama di Kantor Wilayah DJP Jakarta Selatan yaitu sebesar $60.5 \%$. Sosialisasi yang diberikan kepada masyarakat dimaksudkan untuk memberikan pengertian kepada masyarakat akan pentingnya membayar pajak sehingga masyarakat menjadi mengerti dan paham tentang manfaat membayar pajak. Dengan demikian sosialisasi perpajakan dapat berpengaruh meningkatkan kepatuhan wajib pajak (Winerungan ,2012)

Tabel 2. Hasil Pengujian

\begin{tabular}{lcccc}
\hline \multicolumn{1}{c}{ Keterangan } & Std. Beta & Std. Error & t-hitung & Sig. \\
\hline Pemanfaatan TI & 0.059 & 0.031 & 4.164 & 0.000 \\
Sosialisasi Pajak & 0.225 & 0.786 & 4.314 & 0.000 \\
Pengetahuan Pajak & 0.017 & 0.177 & 4.334 & 0.000 \\
R-Square & 0.599 & & & \\
Adjusted R-Square & 0.053 & & & \\
F-hitung & 18.416 & & & \\
Sig. F & 0.000 & & & \\
\hline
\end{tabular}




\section{Pengaruh Pengetahuan Pajak Terhadap Kepatuhan Wajib Pajak.}

Nilai thitung lebih besar daripada ttabel yaitu sebesar 1,690. Karena thitung $>$ ttabel, maka maka Ho ditolak yang artinya dapat disimpulkan bahwa terdapat hubungan yang signifikan antara variabel Pengetahuan Pajak dan Kepatuhan Wajib Pajak pada Kantor Pelayanan Pajak Pratama di Kantor Wilayah DJP Jakarta Selatan. Temuan ini mendukung hasil penelitian Witono (2008) dan Nazir (2010) yang menunjukan bahwa pengetahuan pajak berpengaruh terhadap kepatuhan pajak. Dimana, wawasan seseorang mengenai konsep pajak sesuai dengan Undang Undang perpajakan dapat meningkatkan kepatuhan Wajib Pajak.

Variabel Pengetahuan Pajak yang mempunyai indikator subjek pajak, objek pajak, penghasilan kena pajak, penghasilan tidak kena pajak, tarif pajak penghasilan, biaya, dan perhitungan dimana pengetahuan pajak sudah dapat meningkatkan kepatuhan pajak pada Kantor Pelayanan Pajak Pratama di Kantor Wilayah DJP Jakarta Selatan yaitu sebesar $43.4 \%$. Seperti yang dikemukakan oleh Palil (2013) bahwa the level of tax education and taxknowledge is significant to ensure that the tax administration to be going well. As a result, taxpayers will able to assess their tax liability correctly and to file tax return forms on time ( tingkat pendidikan dan pengetahuan pajak begitu signifikan untuk meyakinkan bawhwa administrasi pajak berjalan dengan baik. Sebagai hasilnya, Wajib Pajak akan mampu menilai kewajiban pajaknya secara benar dan untuk mengajukan formulir pengembalian pajak tepat waktu).

\section{Kesimpulan, Keterbatasan, dan Implikasi Hasil Penelitian}

Berdasarkan hasil penelitian dan pembahasan yang telah diuraikan pada bab sebelumnya, maka dapat ditarik kesimpulan sebagai berikut:

1. Pemanfaatan Teknologi Informasi memiliki pengaruh positif dan signifikan terhadap Kepatuhan Wajib Pajak.
2. Sosialisasi Pajak memiliki pengaruh positif dan signifikan terhadap Kepatuhan Wajib Pajak.

3. Pengetahuan Pajak memiliki pengaruh positif dan signifikan terhadap Kepatuhan Wajib Pajak.

Penelitian selanjutnya disarankan untuk meneliti tentang variabel lain seperti masalah kepatuhan dapat dilihat dari segi keuangan publik (public finance), penegakan hukum (law enforcement), struktur organisasi (organizational structure), tenaga kerja (employees), etika (code of conduct), atau gabungan dari semua segi tersebut.

Peningkatan kualitas pelayanan yang diberikan oleh Kantor Pelayanan Pajak Pratama di Kantor Wilayah DJP Jakarta Selatan yang berkaitan dengan pemanfaatan teknologi informasi dengan langkah konkrit yaitu perlu adanya kerjasama antara Kementrian Komunikasi dan nformasi dengan Kementrian Keuangan dalam hal pengadaan internet yang mudah dijangkau oleh masyarakat, sehingga Wajib Pajak diharapkan lebih mudah mengakses dan melaksanakan kewajiban perpajakan sesuai Peraturan dan Undang Undang Perpajakan yang berlaku.

Peningkatan aktivitas sosialisasi pajak terhadap wajib pajak yang terdaftar pada Kantor Pelayanan Pajak Pratama di Kantor Wilayah DJP Jakarta Selatan khususnya informasi langsung yang diberikan oleh Petugas Pajak. Dalam rangka meningkatkan kesadaran dan kepatuhan Wajib Pajak mengenai pentingnya pajak untuk pembangunan negara yaitu melakukan promosi tentang pajak melalui sosial media, sehingga tumbuh tax minded ditengah masyarakat. Ditumbuhkan kesadaran bahwa membayar pajak adalah kewajiban yang melekat kepada setiap individu untuk kesejahteraan bersama.

\section{Daftar Pustaka}

Andreoni, James, B. Erard and Feinstein, J. (2006). Tax Compliance. Journal of Economic Literature. Vol 36. Issue 2, June 2006. page 818-860. 
Anggraeni, M.D. 2012. Pengaruh Pemanfaatan Fasilitas Perpajakan Sunset Policy Terhadap Tingkat Kepatuhan Wajib Pajak. Skripsi Universitas Diponegoro

Antaranews.com. 25 September 2013. Legislator: rasio pajak Indonesia masih relatif rendah. Jakarta

Aryobimo, Putut, T \& Nur, C. (2012). Pengaruh persepsi wajib pajak tentang kualitas pelayanan fiskus terhadap kepatuhan wajib pajak dengan kondisi keuangan wajib pajak dan preferensi risiko sebagai variabel moderating (Studi empiris terhadap wajib pajak orang pribadi di kota Semarang). Jurnal Akuntansi Vol.1 No.2. Semarang: Fakultas Ekonomika dan Bisnis Universitas Diponegoro Semarang.

Ghozali, Imam. (2011). Aplikasi Analisis Multivariate dengan SPSS. Semarang: Badan Penerbit Undip Semarang.

Kementrian Keuangan Republik Indonesia Direktorat Jenderal Anggaran Direktorat Penyusunan APBN. 2013. Dasar - Dasar Praktek APBN di Indonesia. Jakarta.

Kompas.com. 11 Februari 2013. Sensus Pajak Digiatkan Lagi. Jakarta

Meliono, I., dkk. 2007. Pengetahuan. Dalam: MPKT Modul 1. Jakarta: Lembaga Penerbitan FEUI; 33-35.

Nazir, Nazmel. 2010. Pengaruh Pengetahuan Pajak dan Sistem Administrasi Perpajakan terhadap Kepatuhan Wajib pajak (Survey atas WP OP PBB di KPP Pratama Jakarta Pasar Rebo)

Nasucha, Chaizi. 2004. Reformasi Administrasi Publik: Teori dan Praktik. Jakarta: Penerbit PT Gramedia Widiasarana Indonesia.

Nurmantu, Safri. 2005. Pengantar Perpajakan, Jakarta: Granit

O'erien, James A. 2007. Pengantar Sistem Informasi. Jakarta: Penerbit Salemba Empat,.

Prawirodidirdjo., Suharto Arto. (2007). Analisis pengaruh perubahan organisasi dan budaya organisasi terhadap kepuasan dan kinerja pegawai Direktorat Jenderal Pajak (Penelitian pada Kantor Pelayanan Pajak
Berbasis Administrasi Modern di Lingkungan Kantor Wilayah Jakarta Khusus. Tesis Magister Manajemen, Program Pascasarjana, Universitas Diponegoro. Tidak Dipublikasi.

Raharjo, Eko. 2007. Teori Agensi dan Teori Stewarship Dalam Derspektif Akuntansi Semarang: STIE Pelita Nusantara.

Rahayu. 2010. Perpajakan Indonesia-Konsep dan Aspek Formal. Yogyakarta: Graha Ilmu.

Palil., Rizal., \& Mohd. (2013). The Perception of Tax Payers on Tax Knowledge and Tax Education with Level of Tax Compliance: A Study the Influences of Religiosity. Malaysia: Universiti Kebangsaan Malaysia..

Putri, Emilya. (2012). Pengaruh motivasi, sosialisasi dan kesadaran wajib pajak pribadi dalam membayar pajak. Skripsi. Program Studi Ekonomi Manajemen. Universitas Gunadarma. Jakarta

Soebagyo, Ivan. (2005). Pengaruh sosialisasi oleh Dirjen Pajak terhadap kepatuhan wajib pajak pada KPP Jakarta Kemayoran. Tesis Pasca Sarjana Universitas Indonesia Jawa Barat: Depok.

Soekanto, S. (2002). Kesadaran Hukum dan Kepatuhan Hukum. Jakarta: Rajawali.

Susanto, H. (2012). Membangun Kesadaran dan Kepedulian Sukarela Wajib Pajak. http:// www.pajak.go.id

Widodo, Widi, dkk. (2010). Moralitas, Budaya dan Kepatuhan Wajib Pajak. Bandung: ALFA BETA

Winerungan, O.L. (2013). Sosialisasi perpajakan, pelayanan fiskus, dan sanksi perpajakan terhadap kepatuhan wajib pajak orang pribadi pada Kantor Pelayanan Pajak Pratama Manado dan Kantor Pelayanan Pajak Pratama Bitung. Jurnal EMBA Vol.1 No.3 September 2013, Hal. 960-970.

Witono, Banu. (2008). Peranan pengetahuan pajak pada kepatuhan wajib pajak. Jurnal Akuntansi dan Keuangan, Vol. 7, No. 2, hal 196-208 